\title{
Communication
}

\section{Genetic Characterization of the Belgian Nephropathogenic Infectious Bronchitis Virus (NIBV) Reference Strain B1648}

\author{
Vishwanatha R.A.P. Reddy ${ }^{1}$, Sebastiaan Theuns ${ }^{1}$, Inge D.M. Roukaerts ${ }^{1}$, Mark Zeller ${ }^{2}$, \\ Jelle Matthijnssens ${ }^{2,3}$ and Hans J. Nauwynck ${ }^{1, *}$ \\ ${ }^{1}$ Laboratory of Virology, Department of Virology, Parasitology and Immunology, \\ Faculty of Veterinary Medicine, Ghent University, Salisburylaan 133, B-9820 Merelbeke, Belgium; \\ E-Mails: Reddy.Vishwanatha@ugent.be (V.R.A.P.R.); Sebastiaan.Theuns@UGent.be (S.T.); \\ inge.roukaerts@UGent.be (I.D.M.R.) \\ ${ }^{2}$ Rega Institute for Medical Research, Laboratory of Clinical Virology, Department of Microbiology \\ and Immunology, KU Leuven-University of Leuven, Minderbroedersstraat 10, BE-3000 Leuven, \\ Belgium; E-Mails: mark.zeller@uzleuven.be (M.Z.); jelle.matthijnssens@uzleuven.be (J.M.) \\ ${ }^{3}$ Rega Institute for Medical Research, Laboratory of Viral Metagenomics, Department of \\ Microbiology and Immunology, KU Leuven-University of Leuven, Minderbroedersstraat 10, \\ BE-3000 Leuven, Belgium \\ * Author to whom correspondence should be addressed; E-Mail: Hans.Nauwynck@ugent.be; \\ Tel.: +32-9-264-73-77; Fax: +32-9-264-74-95.
}

Academic Editor: Andrew Mehle

Received: 12 June 2015 / Accepted: 3 August 2015 / Published: 7 August 2015

\begin{abstract}
The virulent nephropathogenic infectious bronchitis virus (NIBV) strain B1648 was first isolated in 1984, in Flanders, Belgium. Despite intensive vaccination, B1648 and its variants are still circulating in Europe and North Africa. Here, the full-length genome of this Belgian NIBV reference strain was determined by next generation sequencing (NGS) to understand its evolutionary relationship with other IBV strains, and to identify possible genetic factors that may be associated with the nephropathogenicity. Thirteen open reading frames (ORFs) were predicted in the B1648 strain (5'UTR-1a-1b-S-3a-3b-E-M-4b-4c-5a-5b-N-6b-3'UTR). ORFs 4b, 4c and 6b, which have been rarely reported in literature, were present in B1648 and most of the other IBV complete genomes. According to phylogenetic analysis of the full-length genome, replicase transcriptase complex, spike protein, partial S1 gene and M protein, B1648 strain clustered with the non-Massachusetts type strains NGA/A116E7/2006, UKr 27-11, QX-like
\end{abstract}


ITA/90254/2005, QX-like CK/SWE/0658946/10, TN20/00, RF-27/99, RF/06/2007 and SLO/266/05. Based on the partial S1 fragment, B1648 clustered with the strains TN20/00, RF-27/99, RF/06/2007 and SLO/266/05 and, further designated as B1648 genotype. The full-length genome of B1648 shared the highest sequence homology with UKr 27-11, Gray, JMK, and NGA/A116E7/2006 (91.2\% to 91.6\%) and was least related with the reference Beaudette and Massachusetts strains (89.7\%). Nucleotide and amino acid sequence analyses indicated that B1648 strain may have played an important role in the evolution of IBV in Europe and North Africa. Further, the nephropathogenicity determinants might be located on the 1a, spike, $M$ and accessory proteins (3a, 3b, 4b, 4c, 5a, 5b and 6b). Overall, strain B1648 is distinct from all the strains reported so far in Europe and other parts of the world.

Keywords: IBV; B1648; nephropathogenic; chicken; nonstructural protein

\section{Introduction}

Infectious bronchitis virus (IBV) belongs to the Nidovirales, family Coronaviridae, subfamily Coronavirinae and genus Gammacoronavirus. Coronaviruses of turkeys, ducks, pheasants, teal and geese, as well as Beluga whale and Bottlenose dolphin coronaviruses are other known members within this genus [1,2]. IBV is an enveloped virus with a positive sense single stranded RNA genome. The genome has a size of approximately $27.6 \mathrm{~kb}$ and contains a methylated cap and poly (A) tail at its $5^{\prime}$ and $3^{\prime}$ end, respectively. IBV contains at least ten open reading frames (ORFs) in the order 5' UTR-1a-1b-S-3a-3b-EM-5a-5b-N-3'UTR [3]. Gene 1 or the replicase transcriptase complex gene is the largest gene $(20 \mathrm{~kb})$ among the ten ORFs. Gene 1 consists of two overlapping ORFs, namely ORF1a and ORF1b, of which the latter is translated in polyprotein 1ab by a ribosomal frameshift. Furthermore, ORF1a and ORF1b encode 15 non-structural proteins (NSPs), which are required for RNA replication, transcription and other aspects of viral replication and pathogenesis. ORFs 2, 3, 4 and 6 encode four major structural proteins: The spike (S) glycoprotein, the small envelope (E) protein, the membrane $(\mathrm{M})$ glycoprotein and the nucleocapsid $(\mathrm{N})$ protein, respectively. The $\mathrm{S}$ protein is cleaved into two subunits, namely $\mathrm{S} 1$ and $\mathrm{S} 2$, of which $\mathrm{S} 1$ is the most variable domain and a major serotype determinant. ORFs 3 and 5 are interspersed between ORFs encoding structural proteins, and encode small non-structural proteins (NSPs), known as 3a, 3b, 5a and 5b [3]. Overall, the IBV genome is genetically variable due to the frequent occurrence of point mutations, insertions, deletions and recombination events [3-5].

IBV affects both broiler and layer chickens. Although chicken flocks are routinely vaccinated with live vaccines, outbreaks of infectious bronchitis have been observed in vaccinated flocks, as there is little or no cross-protection between different IBV serotypes. Hence, serological and molecular characterization of field isolates is very important to select appropriate vaccine strains. IBV has a tropism for the epithelial cells of the respiratory tract, kidney, oviduct and alimentary tract of chickens. In the beginning of the 1950s, the respiratory Massachusetts (Mass) type of IBV was identified in the United States. Later, Mass-type strains have been isolated all over the world and variants emerged. In Europe, at present, Mass 41, 4/91, D274, Italy 02 and QX are recognized as important circulating serotypes $[3,6]$. 
Some IBV strains were described as nephropathogenic since the respiratory infection was followed by a severe renal infection, which leads to clinical signs such as excessive water consumption and wet droppings and increased mortality. Post-mortem examination of birds that died after a nephropathogenic IBV (NIBV) infection reveals dehydrated carcasses and swollen and pale kidneys with urates in the tubules.

The first nephropathogenic IBV strains were reported in the US and Australia, and later in other parts of the world [7-11]. Over the past 15 years, the nephropathogenic IBV strains have been emerging as most predominant IBV strains in poultry industry, especially in Asian and Middle Eastern countries [12-16]. Strain B1648 was responsible for outbreaks of kidney disease on chicken farms in Belgium, The Netherlands and Northern France, and was first isolated in 1984 [6,7,17]. At present, strain B1648 or its variants are still circulating in Europe and North Africa [18-23]. Based on the spike gene analysis of B1648 strain, some of the European, American and West African non-Massachusetts type strains show close genetic relationship with strain B1648 [19,24]. However, conclusions based on the spike gene or partial spike gene segment analysis should be made cautiously, because the true evolutionary relationship of B1648 with other strains can only be evaluated by complete genome analysis. Hence, this paper aims to characterize the complete genome of strain B1648 by means of NGS (Illumina) and aimed to identify the genetic factors, which may be associated with the nephropathogenic nature of this strain.

\section{Materials and Methods}

\subsection{Virus Propagation}

The virulent nephropathogenic IBV strain, B1648 has been isolated in 1984 [17]. Virus stocks were prepared in 10-day-old embryonated SPF chicken eggs by allantoic route inoculation. Then, virus was propagated in embryos for $48 \mathrm{~h}$ at $37^{\circ} \mathrm{C}$. Finally, the allantoic fluid was harvested, clarified by low speed centrifugation and frozen at $-70^{\circ} \mathrm{C}$ until use.

\subsection{Preparation of RNA for Illumina Sequencing}

The virus infected allantoic fluid was filtered twice using $0.8 \mu \mathrm{m}$ and $0.45 \mu \mathrm{m}$ membrane filters. Free and bacterial DNA/RNA was destroyed by the addition of $2 \mu \mathrm{L}$ of Benzonase Nuclease (Novagen, San Diego, CA, USA), $1 \mu \mathrm{L}$ of Micrococcal Nuclease (New England Biolabs, Ipswich, MA, USA) and $1 \mu \mathrm{L}$ of NEBNext ${ }^{\circledR}$ RNase III RNA Fragmentation Module (Invitrogen, Carlsbad, CA, USA) in $7 \mu \mathrm{L}$ of homemade buffer ( $1 \mathrm{M}$ Tris, $100 \mathrm{mM} \mathrm{CaCl}_{2}$ and $30 \mathrm{mM} \mathrm{MgCl}_{2}$ ) that were added to $140 \mu \mathrm{L}$ of allantoic fluid, and incubated for $2 \mathrm{~h}$ at $37^{\circ} \mathrm{C}$. Next, $7 \mu \mathrm{L}$ of EDTA were added to the sample for enzyme inactivation. Extraction of viral RNA was performed using the QIAamp Viral RNA Mini Kit (Qiagen, Hilden, Germany) according to the manufacturer's instructions, but without using carrier RNA. Total RNA was amplified using the Whole Transcriptome Amplification Kit (WTA 2, Sigma Aldrich, St. Louis, MO, USA). Therefore, $0.5 \mu \mathrm{L}$ Library Synthesis Solution was added to $2.82 \mu \mathrm{L}$ of RNA, followed by denaturation for $2 \mathrm{~min}$ at $95{ }^{\circ} \mathrm{C}$. RNA was cooled to $18{ }^{\circ} \mathrm{C}$ and $0.5 \mu \mathrm{L}$ Library Synthesis Buffer, $0.4 \mu \mathrm{L}$ Library Synthesis Enzyme and $0.78 \mu \mathrm{L}$ of water was immediately added to the reaction. The mixture was treated with the following temperature conditions: $18{ }^{\circ} \mathrm{C}, 25^{\circ} \mathrm{C}, 37^{\circ} \mathrm{C}$, 
$42{ }^{\circ} \mathrm{C}$ and $70{ }^{\circ} \mathrm{C}$ for $10,10,30,10$ and $20 \mathrm{~min}$, respectively. Samples were cooled down to $4{ }^{\circ} \mathrm{C}$ followed by a brief centrifugation step. A mastermix containing $60.2 \mu \mathrm{L}$ of nuclease free water, $7.5 \mu \mathrm{L}$ of Amplification Mix, $1.5 \mu \mathrm{L}$ of WTA dNTP mix and $0.75 \mu \mathrm{L}$ Amplification Enzyme was added to the sample and incubated as follows: $94{ }^{\circ} \mathrm{C}$ for $2 \mathrm{~min}$ and 30 cycles at $94{ }^{\circ} \mathrm{C}$ for $30 \mathrm{~s}$ and $70{ }^{\circ} \mathrm{C}$ for 5 min. The resulting cDNA products were purified with the MSB ${ }^{\circledR}$ Spin PCRapace kit (STRATEC Molecular, Birkenfeld, Germany) according to the instructions of the manufacturer and prepared for Illumina sequencing using the KAPA Library Preparation Kit (Kapa Biosystems, Wilmington, NC, USA), according to the manufacturer's instructions.

\subsection{Illumina Sequencing and Sequence Assembly}

Fragments ranging from 350-600 bp were selected using the BluePippin (Sage Science, Beverly, MA, USA) according to the manufacturer's instructions. Sequencing of the samples was performed on a HiSeq 2500 platform (Illumina, San Diego, CA, USA) for 300 cycles (150 bp paired ends). Raw reads were trimmed for quality and adapters, and were de novo assembled into contigs using SPAdes [25]. Scaffolds were classified using a tBLASTx search against all complete viral genomes in GenBank using an $e$-value cut-off of $10^{-10}$. Scaffolds with a significant tBLASTx hit were retained and used for a second tBlastx search against the GenBank nucleotide database using an E-value of $10^{-4}$ [26].

\subsection{Genome Sequence Analysis}

Multiple sequence alignments were performed using the ClustalW plug-in in the MEGA software version 5.2.2, followed by manual editing. The B1648 genome, coding sequence and ORF prediction was carried out in http://covdb.microbiology.hku.hk and http://www.jcvi.org/vigor/ [27,28]. Phylogenetic trees were constructed using the maximum-likelihood method. Substitution models were determined for each gene separately. The bootstrap values were determined from 500 replicates of the original data. Nucleotide and amino acid identities were determined using the p-distance model. The complete genome of strain B1648 was compared to 55 relevant respiratory and nephropathogenic complete IBV genomes of North America (USA), Asia (China, Korea and Taiwan), Africa (Nigeria) and Europe (Sweden, Ukraine and Italy). Partial S1 gene sequences (727 nt) of 90 relevant respiratory and nephropathogenic IBV strains of North America (USA), South America (Argentina), Europe (Sweden, Italy, UK, Slovenia, Ukraine and Russia), Asia (China, India, Israel, Korea and Taiwan), Africa (Tunisia, Nigeria and Egypt) and Australia were compared to B1648 strain as well.

\subsection{Recombination Analysis}

Simplot analysis (SimPlot version 3.5.1) was performed to determine whether the B1648 strain has recombined with other strains during its evolution. Based on the phylogenetic analysis of the complete genome sequence, 10 relevant strains were selected and included in the recombination analysis. The 10 complete genome sequences were aligned using the ClustalW plug-in in the MEGA software version 5.2.2. The Kimura 2-parameter model was used as a distance model, the window size was $500 \mathrm{bp}$ and step size was $60 \mathrm{bp}$. 


\subsection{GenBank Accession Number}

The full-length genomic sequence of the B1648 strain that was described in this report has been deposited in the GenBank database with accession number KR231009.

\section{Results}

\subsection{Genome Organization of Strain B1648}

The complete genome sequence of strain B1648 had a size of 27654 nucleotides (nt), excluding the poly(A)-tail. Thirteen ORFs (5'-1a-1b-S-3a-3b-E-M-4b-4c-5a-5b-N-6b-3') were predicted in the B1648 genome (Table 1). ORFs 4b, 4c and $6 \mathrm{~b}$ were predicted in the B1648 genome and also in most of the GenBank IBV genomes (Table 2). Among the different regions of the genome, the $5^{\prime}$ end untranslated regions (UTR) (518 nt) and $3^{\prime}$ end UTR (292 nt) were most conserved (94.8\% to 99.5\%). On the other hand, the $6 \mathrm{~b}$ protein was the most variable ( $15.9 \%$ to $96 \%)$, followed by $4 \mathrm{c}$ ( $46.4 \%$ to $100 \%), 3 \mathrm{~b}(51.2 \%$ to $96.4 \%$ ) and the Spike protein (56.9\% to $86.2 \%$ ) (Table 2). Deletions, insertions and point mutations were distributed throughout the B1648 genome.

Table 1. Genes, coding regions, nucleotide length and amino acids size of B1648 strain.

\begin{tabular}{ccccc}
\hline Open Reading Frame & Frame & Nucleotide Location & Nucleotide Length (bp) & Amino Acids Size \\
\hline $5^{\prime}$ UTR & - & $1-518$ & 518 & - \\
1a & +3 & $519-12368$ & 11,850 & 3949 \\
1b & +2 & $12443-20401$ & 7959 & 2652 \\
Spike & +3 & $20352-23852$ & 3501 & 1166 \\
3a & +2 & $23852-24025$ & 174 & 57 \\
3b & +1 & $24025-24219$ & 195 & 64 \\
Envelope & +2 & $24200-24484$ & 285 & 94 \\
Membrane & +3 & $24477-25154$ & 678 & 225 \\
4b & +3 & $25155-25439$ & 285 & 94 \\
4c & +1 & $25360-25530$ & 171 & 56 \\
5a & +2 & $25514-25711$ & 198 & 65 \\
5b & +1 & $25708-25956$ & 249 & 82 \\
Nucleocapsid & +3 & $25899-27128$ & 1230 & 409 \\
6b & +2 & $27137-27361$ & 225 & 74 \\
$3^{\prime}$ UTR & - & $27362-27654$ & 292 & - \\
\hline
\end{tabular}


Table 2. Nucleotide and amino acid sequence identity (\%) of B1648 genome with relevant genomes of Infectious Bronchitis Virus (IBV).

\begin{tabular}{|c|c|c|c|c|c|c|c|c|c|c|c|c|c|c|c|c|}
\hline Strain & Genome & & $1 a$ & $1 \mathrm{~b}$ & Spike & $3 \mathbf{a}$ & $3 b$ & $\mathrm{E}(\mathbf{3 c})$ & $\mathbf{M}$ & $4 b$ & $4 c$ & $5 a$ & $5 b$ & $\mathbf{N}$ & $6 b$ & $\mathbf{3}^{\prime}$ \\
\hline Beaudette & 89.7 & 96.2 & $.7 / 91.7$ & $.9 / 96.6$ & $80.7 / 80.7$ & $91.1 / 94.6$ & $80.1 / 64.6$ & $88.9 / 81.8$ & $95.1 / 93$ & $90.2 / 85.8$ & $87.1 / 84.2$ & $83.4 / 84.8$ & $95.3 / 90.8$ & $92.4 / 93.6$ & $93.6 / 93.9$ & 99.1 \\
\hline California99 & 90.4 & 98.1 & $90.1 / 91.9$ & 93/97.1 & 79.2/84.1 & $87.8 / 82.8$ & $96.6 / 96.4$ & $92.3 / 90.7$ & $93.9 / 91.5$ & $89.6 / 87.5$ & $89.0 / 89.7$ & $86.5 / 88.4$ & $93.6 / 86.6$ & $93.4 / 96$ & $68.9 / 65.2$ & 98.1 \\
\hline Cal5572003 & 90.4 & 98.4 & 90.3 & $92.9 / 97.2$ & $79.5 / 83$ & $93.7 / 94.6$ & $89.8 / 80.7$ & $93.5 / 91.9$ & $94.4 / 91.5$ & $83.7 / 76.9$ & $64.4 / 50.5$ & $87.1 / 86.6$ & $94.4 / 86.6$ & $93.3 / 94.7$ & $94.3 / 96$ & 98.1 \\
\hline Cal56b & 90.6 & 97.8 & $90.7 / 92.1$ & $92.9 / 97$ & $77.8 / 82.8$ & $89.2 / 85.9$ & $94.8 / 92.7$ & $91.5 / 88.2$ & $95.1 / 93$ & $85.5 / 82.4$ & $66.0 / 50.5$ & $88.3 / 88.4$ & $94.5 / 90.8$ & $94.1 / 96.2$ & $93 / 93.9$ & 98.6 \\
\hline SAIBK & 86.8 & 95.8 & $86.4 / 89.4$ & $89.5 / 95.5$ & $78 / 81.7$ & $90.9 / 79.6$ & $76.2 / 67.1$ & $88.5 / 85.7$ & $92 / 90.4$ & $83 / 82.4$ & $64.4 / 46.4$ & $87.2 / 91.9$ & $93.6 / 89.5$ & $85.7 / 91.8$ & NA & 97.6 \\
\hline TW2575/98 & 86.0 & 95.5 & $84.8 / 87.9$ & $88.9 / 95.7$ & $79.2 / 81.7$ & 94.8/97.3 & $87.3 / 80.7$ & $90.5 / 87$ & $92.7 / 90.4$ & $83.7 / 80.6$ & $85.1 / 81.3$ & $86.3 / 88.4$ & $92.6 / 85.2$ & $88.4 / 92$ & $68.3 / 65.2$ & 97.1 \\
\hline ArkDPI11 & 90.8 & 98.7 & $90.6 / 92.2$ & 93/96.9 & $80.7 / 83.7$ & $97.4 / 94.6$ & $96.6 / 94.6$ & 93/91.9 & $93.6 / 92$ & $89.6 / 87.5$ & 89.9/92.4 & $86.5 / 88.4$ & $94.9 / 89.5$ & $94.2 / 96.5$ & $94.3 / 96$ & 98.1 \\
\hline $\mathrm{H} 52$ & 89.6 & 97.8 & $89.4 / 91.5$ & $92.1 / 96.5$ & $80.9 / 80.6$ & $85.1 / 88.9$ & $81.5 / 67.1$ & $88.9 / 81.8$ & $95.4 / 93$ & $88.5 / 85.8$ & $85.2 / 78.3$ & $87.8 / 88.4$ & $92.6 / 85.2$ & 91.9/94.7 & $34.7 / 15.9$ & 98.6 \\
\hline H120 & 90.4 & 98.7 & $89.9 / 91.7$ & 93.6/97.4 & $79 / 81.1$ & $85.1 / 88.9$ & $80.7 / 67.1$ & $87.6 / 76.3$ & $96.2 / 92.5$ & $88.5 / 85.8$ & $85.2 / 78.3$ & $88.4 / 88.4$ & $95.3 / 90.8$ & $93.4 / 94.7$ & $34.7 / 15.9$ & 99.0 \\
\hline Mass412006 & 90.8 & 98.7 & $91.1 / 92.6$ & $92.5 / 97$ & $83.1 / 82.3$ & $87.8 / 82.8$ & $96.6 / 96.4$ & 93.5/93.1 & $93.7 / 92$ & $89.6 / 87.5$ & $89.9 / 92.4$ & $86.5 / 88.4$ & $94.4 / 88.1$ & 94.4/96.7 & $93 / 93.9$ & 98.6 \\
\hline Mass411985 & 89.7 & 96.8 & $89.6 / 91.4$ & $92.2 / 96.7$ & $58.3 / 80.8$ & $91.1 / 91.8$ & $81.5 / 67.1$ & $89.5 / 83.1$ & $94.8 / 93$ & $90.9 / 89.1$ & $89.2 / 81.3$ & $86.6 / 83$ & $92.6 / 83.7$ & $91.9 / 94.7$ & NA & 98.1 \\
\hline Conn461996 & 91.1 & 97.8 & $91.5 / 92.7$ & $93.1 / 97$ & $58.6 / 82.5$ & $87.8 / 82.8$ & $96.6 / 96.4$ & $93.3 / 93.1$ & $93.6 / 92$ & $89.6 / 87.5$ & $89.9 / 92.4$ & $86.5 / 88.4$ & $94.9 / 89.5$ & 94.4/96.7 & $89.5 / 91.8$ & 98.6 \\
\hline ITA/90254/2005 & 90.2 & 97.1 & 92.2/94.2 & $90.8 / 96.3$ & $80.5 / 81.8$ & $85.7 / 79.6$ & $64.1 / 54$ & $89.2 / 84.4$ & $95.6 / 94.6$ & $93.4 / 92.4$ & $92.7 / 89.7$ & $90.1 / 91.9$ & $92.6 / 86.6$ & $91.3 / 94.9$ & $97.5 / 96$ & 99.0 \\
\hline NGA/A116E7/2006 & 91.6 & 97.8 & 92.2/94 & $93 / 96.8$ & $81.7 / 84.8$ & $90 / 79.6$ & $78.1 / 64.6$ & $92 / 90.7$ & $89.9 / 85.5$ & $92.4 / 90.8$ & $91.9 / 89.7$ & $93.5 / 91.9$ & $93.5 / 88.1$ & $92.8 / 95.2$ & $94.2 / 89.7$ & 98.6 \\
\hline Delaware072 & 88.1 & 98.4 & $89.1 / 90.5$ & $91 / 94.2$ & $81.4 / 57.5$ & $92.8 / 82.8$ & $96.6 / 96.4$ & $92.9 / 90.7$ & $94.7 / 93$ & $88.5 / 85.8$ & $85.1 / 78.3$ & $85.3 / 88.4$ & $94.9 / 89.5$ & $92.9 / 94.4$ & $92.9 / 93.9$ & 98.6 \\
\hline Gray & 91.2 & 98.7 & $91.8 / 93.3$ & $92.6 / 97.2$ & $78.6 / 82.8$ & $97.4 / 94.6$ & $96.6 / 94.6$ & $92.6 / 91.9$ & $88.2 / 81.6$ & $89.6 / 85.8$ & $89.9 / 92.4$ & $86.5 / 88.4$ & $93.1 / 86.6$ & $86.1 / 84.5$ & $94.9 / 96$ & 96.6 \\
\hline Holte & 90.7 & 98.7 & $91.5 / 92.8$ & $92.2 / 97$ & $79 / 80.2$ & $91.9 / 88.9$ & $94.2 / 88.9$ & $91.4 / 89.5$ & $94.9 / 92$ & $87.9 / 82.4$ & $89.1 / 84.2$ & $83.3 / 86.6$ & $95.8 / 92.2$ & $91.2 / 93.4$ & NA & NA \\
\hline Iowa97 & 90.6 & 98.4 & $91.3 / 92.4$ & $92.2 / 97$ & $77.7 / 82.7$ & $91.9 / 88.9$ & $94.2 / 88.9$ & $91.4 / 89.5$ & $94.5 / 91.5$ & $87.9 / 82.4$ & $89.1 / 84.2$ & $83.3 / 86.6$ & 95.8/92.2 & $91.5 / 93.9$ & $91.5 / 89.7$ & 96.6 \\
\hline JMK & 91.2 & 98.7 & $92 / 93.5$ & $92.5 / 97$ & $79.1 / 82.3$ & $97.4 / 94.6$ & $96 / 92.7$ & $92.6 / 91.9$ & $94.1 / 92$ & $89.6 / 85.8$ & $89.9 / 92.4$ & $86.5 / 88.4$ & $93.1 / 86.6$ & $93.6 / 94.9$ & NA & 98.1 \\
\hline $\mathrm{CK} / \mathrm{CH} / \mathrm{LDL} / 101212$ & 90.4 & 98.4 & $89.8 / 91.6$ & 93.6/97.3 & $78.8 / 81.2$ & $85.1 / 88.9$ & $80.7 / 67.1$ & $87.6 / 76.3$ & $96.2 / 92.5$ & $88.5 / 85.8$ & $85.2 / 78.3$ & $87.8 / 86.6$ & $95.3 / 90.8$ & $93.2 / 94.4$ & $34.7 / 15.9$ & 98.1 \\
\hline CK/SWE/0658946/10 & 89.5 & 96.8 & 90/91.1 & $91.3 / 95.8$ & $80 / 80.8$ & $83.6 / 76.4$ & $64.9 / 51.2$ & 93.7/88.2 & $96.1 / 95.6$ & $91.3 / 92.4$ & $92.0 / 81.3$ & $94.7 / 98.4$ & $91.2 / 85.2$ & $89.2 / 90.4$ & $97.5 / 96$ & 99.0 \\
\hline KM91 & 90.0 & 98.7 & $91.1 / 92.6$ & $91.7 / 96.6$ & $62.4 / 80.4$ & $87.8 / 69.5$ & $78.8 / 74.1$ & $89.6 / 89.5$ & $94.3 / 93.5$ & $92.5 / 92.4$ & $93.6 / 95.0$ & $86 / 84.8$ & $93.1 / 86.6$ & $92.5 / 95.5$ & $71.4 / 73.2$ & 96.6 \\
\hline $\mathrm{CK} / \mathrm{CH} / \mathrm{LJL} / 111054$ & 90.7 & 98.7 & $90.2 / 92.1$ & $93.6 / 97.3$ & $84.6 / 82.6$ & $87.8 / 82.8$ & $96.6 / 96.4$ & $93.3 / 93.1$ & $93.7 / 92$ & $89.6 / 87.5$ & $89.9 / 92.4$ & $86.5 / 88.4$ & $94.9 / 89.5$ & $94.4 / 96.7$ & $90.2 / 91.8$ & 98.6 \\
\hline Ukr27-11 & 91.2 & 96.5 & $89.8 / 91.7$ & 93.6/97.2 & $80.8 / 86.2$ & 98.3/97.3 & 93/92.7 & $92.3 / 91.9$ & 96.9/96.6 & 97.6/97 & $96.9 / 100.0$ & $94.7 / 93.5$ & $94.4 / 89.5$ & 93.2/95.2 & 97.5/96 & 99.0 \\
\hline $\mathrm{CK} / \mathrm{CH} / \mathrm{LDL} / 110931$ & 90.6 & 98.7 & $89.9 / 91.7$ & $93.6 / 97.3$ & $80.7 / 82.4$ & $87.8 / 82.8$ & $96.6 / 96.4$ & $93.3 / 93.1$ & $93.7 / 92$ & $89.6 / 87.5$ & $89.9 / 92.4$ & $86.5 / 88.4$ & $94.9 / 89.5$ & $\mathbf{9 4 . 4} / 96.7$ & $90.2 / 91.8$ & 98.6 \\
\hline
\end{tabular}

Boldface indicates the highest, and italic the lowest, nucleotide and amino acid sequence identity. 


\subsection{Phylogenetic Analysis and Comparison Alignments of Full Genomes of IBV Strains}

The general time reversible model with gamma distribution and invariant sites was used for the construction of a maximum likelihood phylogenetic tree of the 55 relevant respiratory and nephropathogenic complete IBV genomes of North America (USA), Asia (China, Korea and Taiwan), Africa (Nigeria) and Europe (Sweden, Ukraine and Italy) (Figure 1). The phylogenetic analysis of 55 full-length nucleotide sequences of different IBV strains has demonstrated that NGA/A116E7/2006 (non-Mass pathogenic variable type of Nigeria), UKr 27-11 (non-Mass recombinant type of Ukraine), QX-like ITA/90254/2005 (non-Mass type of Italy) and QX-like CK/SWE/0658946/10 (non-Mass type of Sweden) strains clustered most closely with B1648.

\section{Full genome}

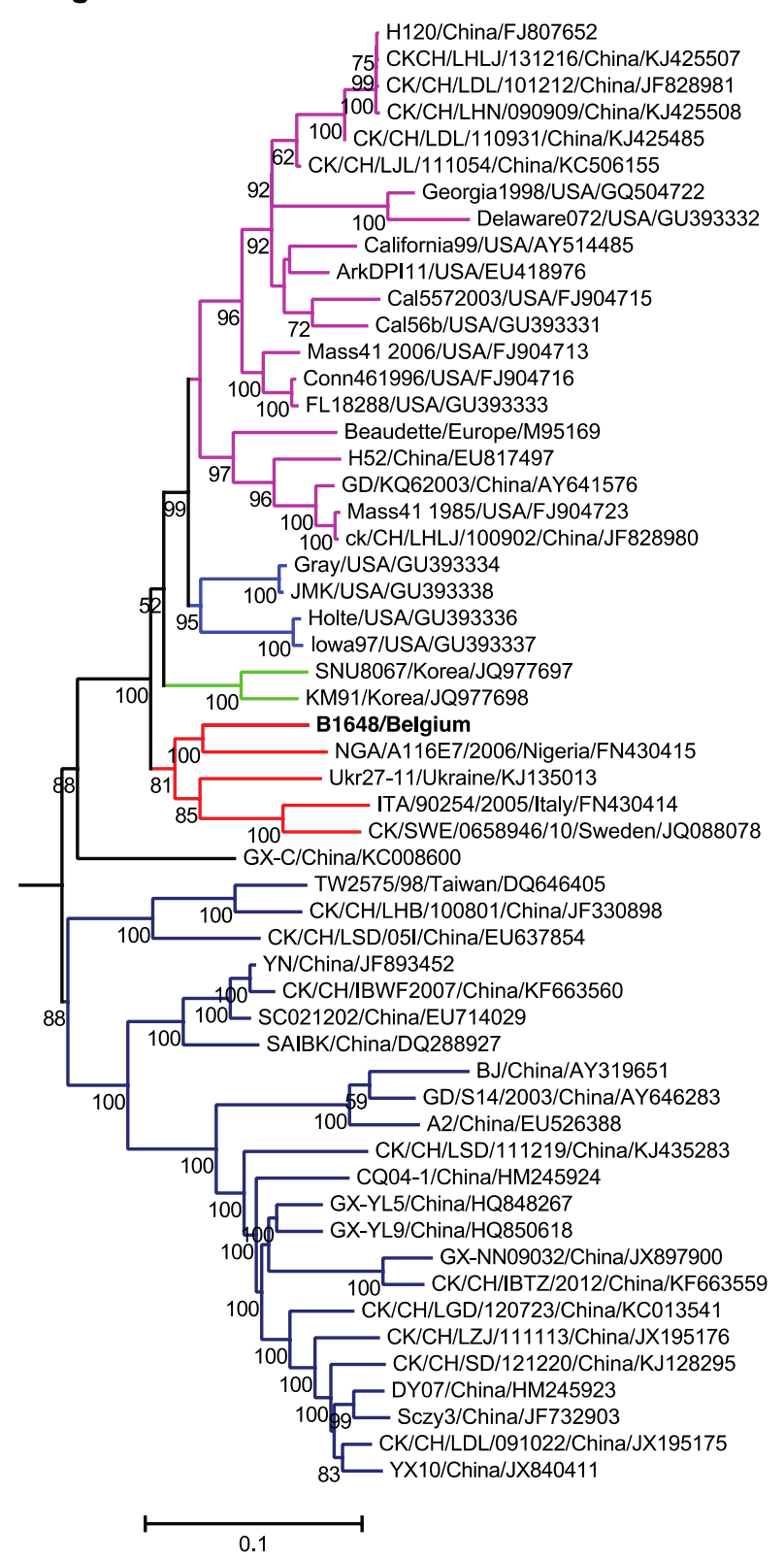

Figure 1. Maximum likelihood phylogenetic tree based on 55 full genome sequences. Bootstrap values ( $n=500$ replicates) of $<50 \%$ are not shown. Strain B1648 cluster is shown in red. 
The B1648 strain has the highest nucleotide sequence homology with strains UKr 27-11, Gray (non-Mass nephropathogen), JMK (non-Mass respiratory pathogen) and NGA/A116E7/2006 (91.2\% to 91.6\%) (Table 2). Strain B1648 was clustered distinctly from all the Mass type strains. The nucleotide sequence homology to Mass 41 (M41, 1985) and reference (Beaudette) strain was $89.7 \%$.

\subsection{Phylogenetic Analysis and Sequence Comparison of Spike Protein (1166 aa) and Partial S1 Gene (727 nt)}

Maximum likelihood trees were constructed for the amino acid sequences of the spike protein and nucleotide sequences of the partial S1 gene using the general time reversible and Tamura 92 models with gamma distribution sites, respectively (Figure 2). The phylogenetic analysis of the spike protein (1166 aa) clustered NGA/A116E7/2006 and Ukr27-11 with B1648 strain. The phylogenetic analysis of 90 partial S1 genes (727 nt) of relevant respiratory and nephropathogenic IBV strains of North America (USA), South America (Argentina), Europe (Sweden, Italy, UK, Slovenia, Ukraine and Russia), Asia (China, India, Israel, Korea and Taiwan), Africa (Tunisia, Nigeria and Egypt) and Australia has clustered B1648 strain with TN20/00 (Tunisian), RF-27/99 and RF/06/2007 (Russian) and SLO/266/05 (Slovenian) strains.

The Spike protein of B1648 showed the highest amino acid identities to California99, NGA/A116E7/2006 and Ukr27-11 (84.1\% to 86.2\%). The partial S1 gene of B1648 strain showed the highest nucleotide homology with strains SLO/266/05, RF/06/2007, RF-27/99 and TN20/00 (89.4\% to $97.4 \%$ ). According to amino acid sequence identity, the Spike protein (56.9\% to 86.2\%) was the fourth most variable region (Table 2).

\subsection{Phylogenetic Analysis and Comparison Alignments of the Replicase Transcriptase Complex (Polyprotein $1 a(3949 a a)$ and $1 b(2652 a a)$ )}

The replicase transcriptase complex (polyprotein 1a (3949 aa) and 1b (2652 aa)) maximum likelihood trees were constructed using the general time reversible model with gamma distribution and invariant sites (Figure 3). Based on the phylogenetic analysis of the replicase protein complex amino acid sequences, B1648 clustered with NGA/A116E7/2006 (1a, 1b), ITA/90254/2005 (1a) and UKr 27-11 (1b).

Polyprotein 1a (3949 aa) had the highest amino acid homology with strains Gray, NGA/A116E7/2006 and ITA/90254/2005 (93.3\% to $94.2 \%)$, while polyprotein $1 \mathrm{~b}(2652$ aa) was closest to $\mathrm{CK} / \mathrm{CH} / \mathrm{LDL} / 101212$, CK/CH/LHLJ/131216 and H120 (97.3\% to 97.4\%). Overall, polyprotein 1b (95.3\% to $97.4 \%$ ) was more conserved than 1a (84.8\% to $94.6 \%)$ (Table 2). Among the 15 NSPs of polyprotein $1 \mathrm{ab}, \mathrm{NSP} 3$ (80.6\% to $92.4 \%)$, NSP9 (69.1\% to $99.1 \%)$ and NSP11 (69.8\% to $86 \%)$ were most variable, whereas the other NSPs were generally more conserved $(82.8 \%$ to $100 \%)$ (Supplementary Table S1). 


\section{Spike}

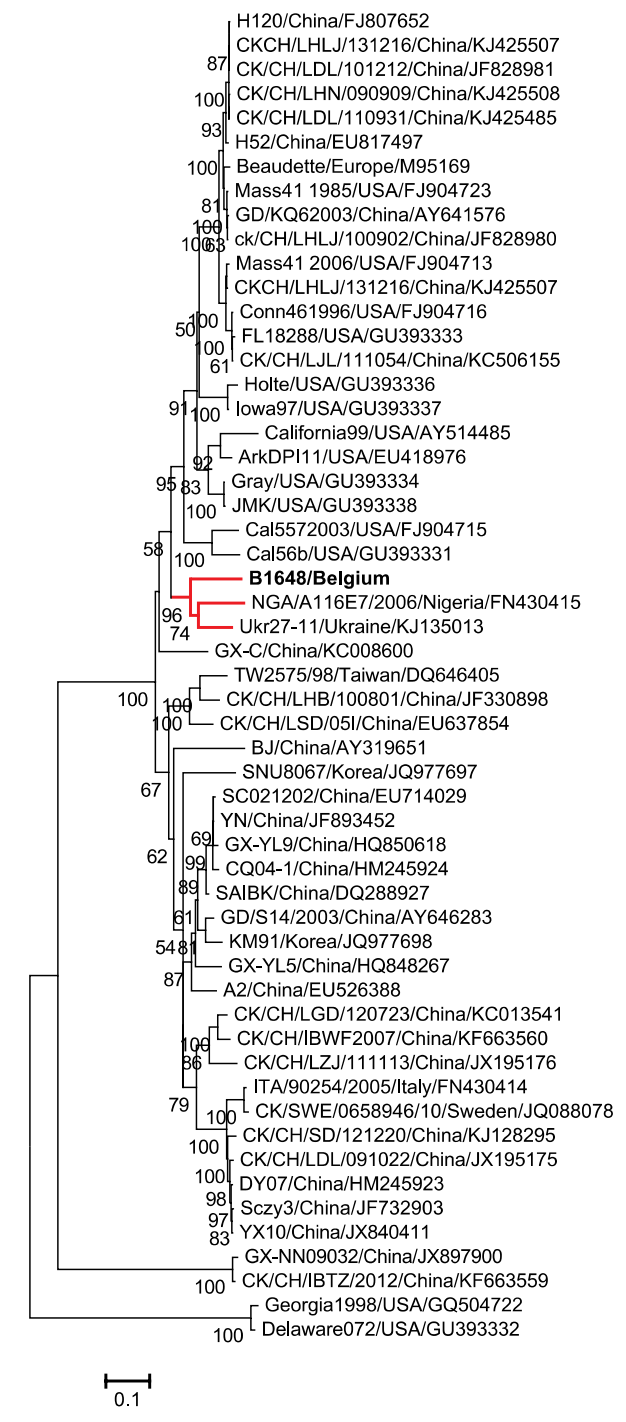

\section{Partial S1}

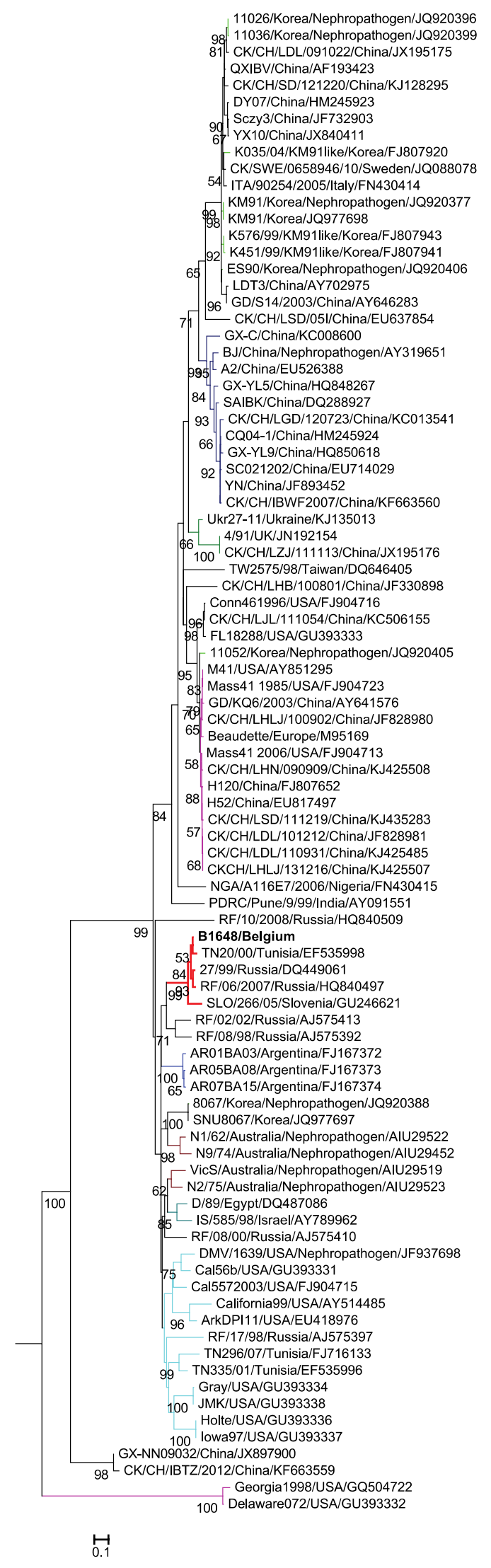

Figure 2. Maximum likelihood phylogenetic trees based on amino acid sequences of spike protein and nucleotide sequences of partial S1 gene. Bootstrap values ( $n=500$ replicates) of $<50 \%$ are not shown. Strain B1648 cluster is shown in red. 
$1 \mathrm{a}$

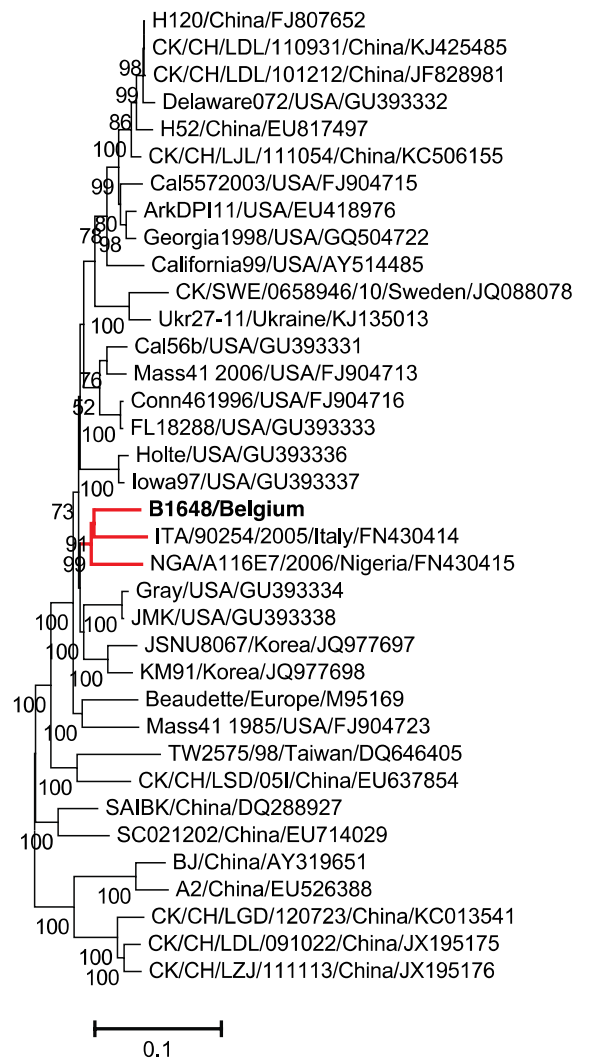

$1 b$

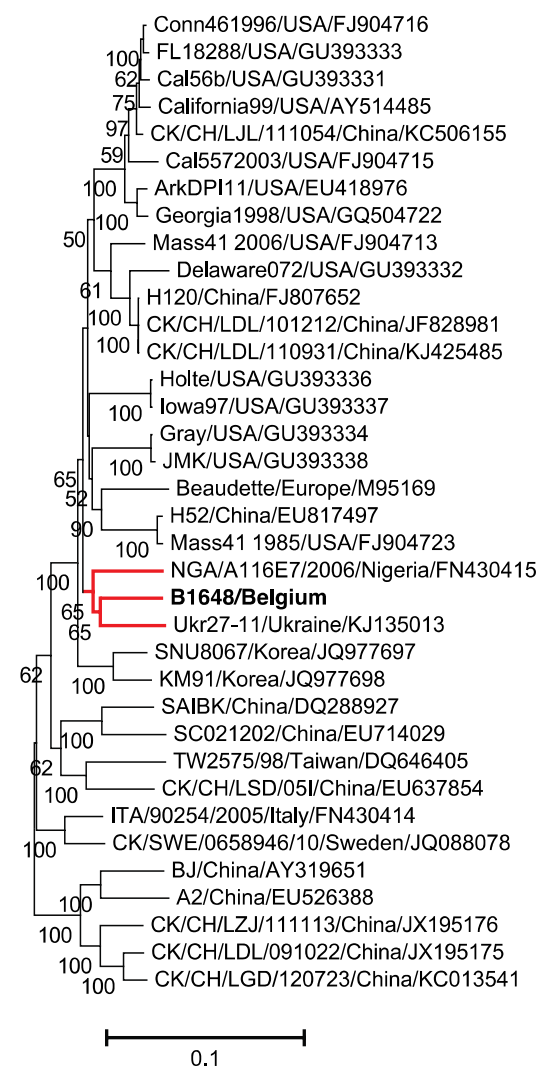

$\mathbf{N}$

\section{$E(3 c)$}

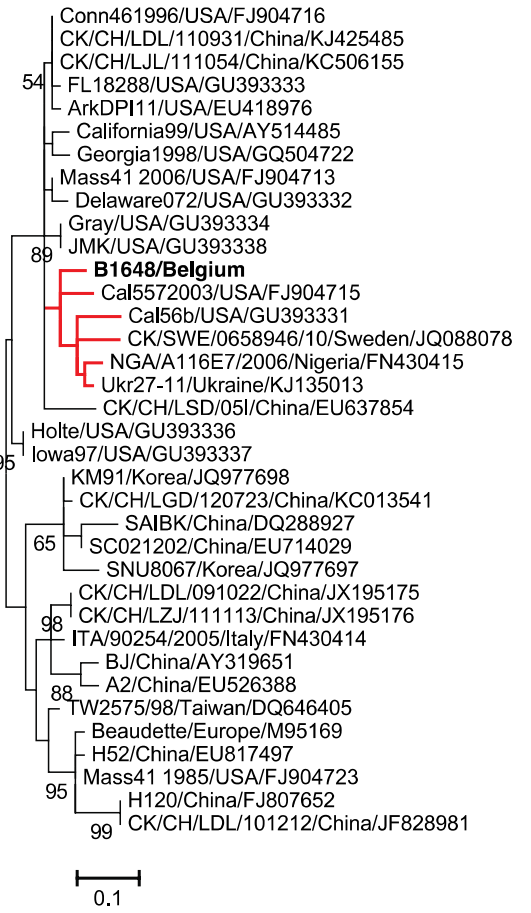

M

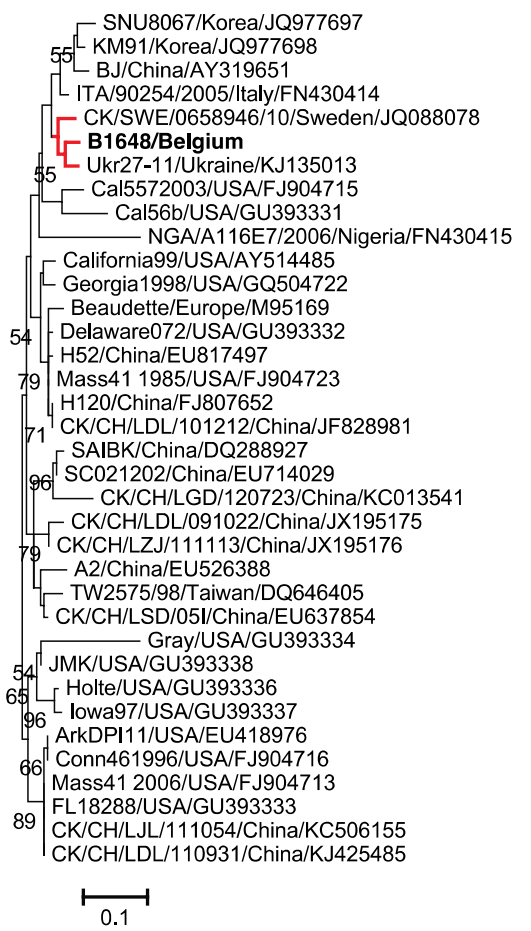

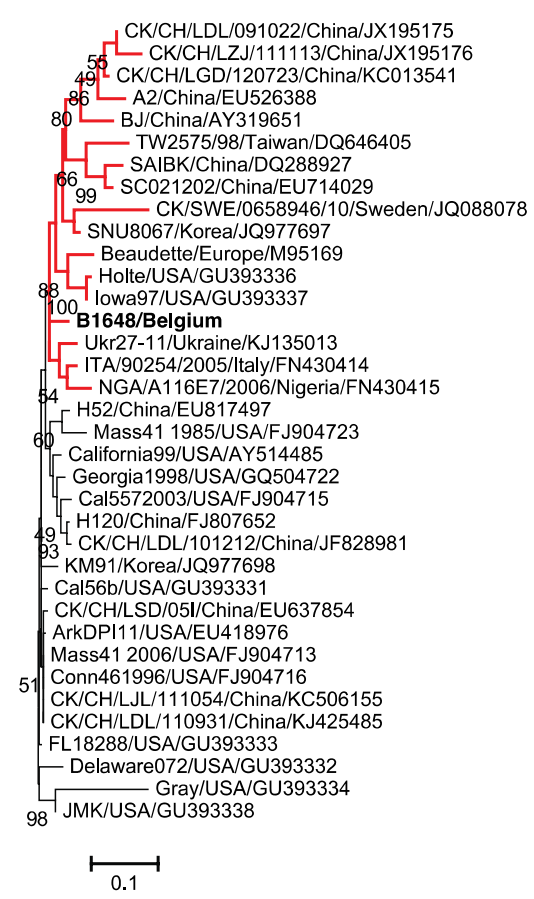

Figure 3. Maximum likelihood phylogenetic trees based on amino acid sequences of $1 \mathrm{a}, 1 \mathrm{~b}$, $\mathrm{E}$ (3c), $\mathrm{M}$ and $\mathrm{N}$ proteins. Bootstrap values $(n=500$ replicates) of $<50 \%$ are not shown. Strain B1648 cluster is shown in red. 
3.5. Phylogenetic Analysis and Sequence Comparison of Amino Acid Sequences of E, M and N Proteins

For construction of E or 3c (94 aa), M (225 aa) and N (409 aa) proteins maximum likelihood trees, the Jones Thornton Taylor model with gamma distribution sites was used (Figure 3). Based on the phylogenetic analysis of amino acid sequences of E protein, NGA/A116E7/2006, Ukr27-11, Cal5572003, Cal56b and many other Mass and non-Mass type strains were clustered together with B1648. Further, a sequence of 12 amino acids (36 nucleotides) was discontinuously deleted in the C-terminal of the B1648 E protein. The same 12 amino acids were deleted in strains NGA/A116E7/2006, Ukr27-11, Cal5572003 and Cal56b (Figure 4). According to amino acid sequences of the M protein, B1648 strain was clustered with NGA/A116E7/2006, UKr 27-11, QX-like ITA/90254/2005, QX-like CK/SWE/0658946/10 and many other non-Mass type strains. Based on the amino acid sequences of $\mathrm{N}$ protein, NGA/A116E7/2006, UKr 27-11, QX-like ITA/90254/2005, Beaudette, Mass type (1985) and many other Mass type and non-Mass type strains were clustered together with B1648.

The E or 3c (94 aa) protein had the highest amino acid identities to Mass 41(2006), Conn461996, CK/CH/LDL/110931 and CK/CH/LJL/111054 (93.1\%). The M protein (225 aa) was closest to ITA/90254/2005, CK/SWE/0658946/10 and Ukr27-11 (94.6\% to 96.6\%). The N protein (409 aa) showed the highest amino acid identities to Mass 41(2006), and many other Mass and non-Mass type strains $(96.7 \%)$.

$\begin{array}{lc}\text { ITA/90254/2005/Italy/FN430414 } & \text { VNEFPKNGWNNKNPAIFQDVERHGKLHS* } \\ \text { CK/SWE/0658946/10/Sweden/JQ088078 } & \text { VNDFPKNGWNNKNPAIFQDVEPHHQLHS* } \\ \text { Beaudette/Europe/M95169 } & \text { VNEFPKNGWNNKNPANFQDAQRD-KLYS* } \\ \text { H52/China/EU817497 } & \text { VNEFPKNGWNNKNPANFQDVQRD-KLYS* } \\ \text { H120/China/FJ807652 } & \text { VNEFPKNGWNNKNPANFQDVQRN-KLYS* } \\ \text { Mass41 1985/USA/FJ904723 } & \text { VNEFPKNGWNNKNPANFQDVQRD-KLYS* } \\ \text { Mass41 2006/USA/FJ904713 } & \text { VNEFPKNGWNNKSPANFQY---DGKLHT* } \\ \text { ArkDPI11/USA/EU418976 } & \text { VNEFPKNGWNNKSPANFQY---DGKLHT* } \\ \text { Conn461996/USA/FJ904716 } & \text { VNEFPKNGWNNKSPANFQY---DGKLHT* } \\ \text { Gray/USA/GU393334 } & \text { VNEFPKNGWNNKIPENFQH---GGKLHT* } \\ \text { Holte/USA/GU393336 } & \text { VNEFPKNGWNNKNPANFQY---GGKLHT* } \\ \text { B1648/Belgium } & \text { VNEFPKNGWK-------Y----G*---- } \\ \text { NGA/A116E7/2006/Nigeria/FN430415 } & \text { VNEFPKNGWK*-------------- } \\ \text { Ukr27-11/Ukraine/KJ135013 } & \text { VNEFPKNGWKN-----------G*---- } \\ \text { Cal557 2003/USA/FJ904715 } & \text { VNEFPKNGWKQ*-------------- } \\ \text { Cal56b/USA/GU393331 } & \text { VNEFPKNGWKQ*------------- } \\ \text { KM91/Korea/JQ977698 } & \text { VNEFPKNGWNNKNPAIFQDVERHGKLHS* }\end{array}$

Figure 4. Amino acid sequence differences in C-terminal of E protein of B1648 strain with other Mass (red) and non-Mass type strains. In the B1648 strain $3^{\prime}$ terminal E (3c) protein, a region of total 12 amino acids was discontinuously deleted (blue). The dashes (-) indicate the deleted sequences. 


\subsection{Accessory Proteins Alignments}

There were 7 probable accessory proteins in the B1648 strain, such as 3a (57 aa), 3b (64 aa), 4b (94 aa), 4c (56 aa) 5a (65 aa), 5b (82 aa) and 6b (74 aa). The accessory proteins 3a (69.5\% to $97.3 \%), 3 \mathrm{~b}$ (51.2\% to $96.4 \%), 4 \mathrm{~b}(76.9 \%$ to $97 \%), 4 \mathrm{c}(46.4 \%$ to $100 \%)$ and $6 \mathrm{~b}(15.9 \%$ to $96 \%)$ were variable whereas $5 \mathrm{a}(81.1 \%$ to $93.5 \%)$ and $5 \mathrm{~b}(82.3 \%$ to $92.2 \%)$ were more conserved (Table 2$)$. The highest amino acid identities of 3a, 3b, 4b, 4c, 5a, 5b and 6b were 97.3\% (Ukr27-11 and TW2575/98), 96.4\% (CK/CH/LDL/110931, California99 and many other non-Mass type strains), 97\% (Ukr27-11), 100\% (Ukr27-11), 98.4\% (CK/SWE/0658946/10), 92.2\% (Holte and Iowa97) and 96\% (Ukr27-11, CK/SWE/0658946/10, Gray, ArkDPI11 and many other non-Mass type strains), respectively.

\subsection{Recombination Analysis}

B1648 was used as a putative parental strain and 10 relevant pathogenic and vaccine strains were queried in the Simplot analysis (Figure 5). The B1648 strain was considered as parental strain, because the strains that clustered with B1648 (Figures 1-3), were reported after the B1648 outbreak. In gene 1a, a part of NSP2 and NSP4 showed a higher similarity to ITA/90254/2005; a part of NSP3 showed a higher similarity to ITA/90254/2005 and NGA/A116E7/2006, and part of NSP6 showed a higher similarity to CK/SWE/0658946/10. In the gene 1b, a part of NSP13 and NSP14 shared a higher similarity with NGA/A116E7/2006, and a part of NSP15 did that with UKr 27-11. In the S gene, a part of the S1 region showed similarities with Gray and UKr 27-11 and a part of S2 did that with NGA/A116E7/2006. The $4 \mathrm{~b}, 4 \mathrm{c}$ and $5 \mathrm{a}$ genes were very similar to those of UKr 27-11.
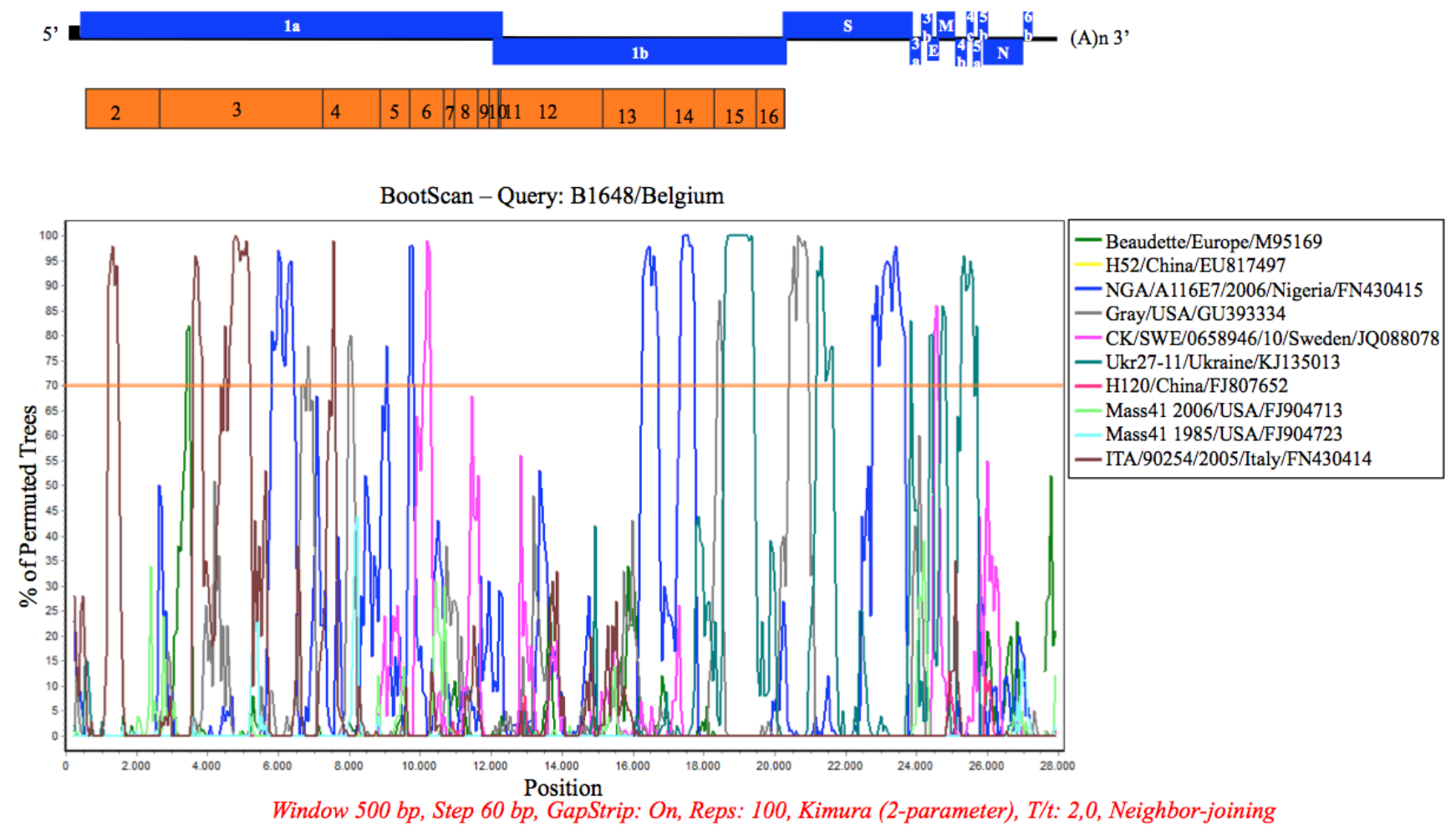

Figure 5. Simplot analysis (Simplot 3.5.1) of B1648 strain. The full genome sequence of B1648 strain was tested against 10 relevant IBV strains. The $70 \%$ bootstrap level is considered. 


\section{Discussion}

The B1648 strain is a Belgian reference nephropathogenic IBV serotype. Earlier, in our laboratory it was demonstrated that B1648 was antigenically different from the Mass type and other variant strains. Furthermore, it was shown that Mass type vaccines (H120 and D274) did not provide protection [17,29]. More recently, Cook et al. [30] found that the 4/91 type (variant type) vaccine alone or the 4/91 and Ma5 (Mass type) combination vaccine protected against B1648 nephropathogenicity. In spite of the intensive vaccination program, the B1648 strain or its variants are still circulating or reemerging throughout Europe and North Africa [18-23]. Hence, in the present study the complete genome of the B1648 strain was characterized to identify putative genetic factors that may be involved in the tissue tropism, and to understand their role in evolution [7,17,29].

The B1648 genome organization (5'-1a-1b-S-3a-3b-E-M-4b-4c-5a-5b-N-6b-3') was slightly different from most previously reported IBV genomes (5'-1a-1b-S-3a-3b-E-M-5a-5b-N-3'). 4b, 4c and 6b were additional ORFs present in the B1648 genome. Although 4b, 4c and $6 \mathrm{~b}$ were present in the most of the IBV genomes, they have rarely been reported in literature [31-33]. ORFs $4 b, 4 c$ and $6 b$ have also been reported in a turkey coronavirus [34]. The exact reason for the rare reports of these ORFs (4b, 4c and $6 \mathrm{~b}$ ) in most of the IBV genomes is not known. It could be that $4 b, 4 c$ and $6 b$ ORFs are present in most of the IBV genomes, but that the success of their identification depends on the algorithms of ORF prediction software that was used. Recently, Bentley et al. [35] has demonstrated and confirmed 4b as a 5 th accessory protein in IBV, besides $3 a, 3 b, 5 a$ and $5 b$. The $4 b$ homologue of Middle East respiratory syndrome coronavirus (MERS-CoV) was found to be an interferon antagonist [36]. The 6b homologue of SARS coronavirus was found to induce apoptosis [37]. For IBV, further investigations are necessary to demonstrate the production of $4 \mathrm{~b}, 4 \mathrm{c}$ and $6 \mathrm{~b}$ proteins and to identify their functions in pathogenesis.

The phylogenetic analysis of the full-length genome, replicase transcriptase complex, spike protein, partial S1 gene and M protein has suggested that B1648 may have played an important role in evolution, because the strains which were clustered (NGA/A116E7/2006, UKr 27-11, QX-like ITA/90254/2005, QX-like CK/SWE/0658946/10, TN20/00, RF-27/99, RF/06/2007 and SLO/266/05) with B1648 were reported in Europe and North Africa, after the initial B1648 outbreak. The geographical proximity of all these countries and frequent movements of poultry and their products in between these countries might be an important reason for this observed cluster. All the above clustered strains belong to a group referred to as non-Mass type strains. In the above-mentioned cluster, QX like ITA/90254/2005 and QX like CK/SWE/0658946/10 are presently predominant IBV strains in Europe (Germany, The Netherlands, Belgium, France, Sweden, Poland, Russia, Slovenia, Spain and the UK) [9,38-44]. The QX IBV strains were first reported in China in 1996, which were usually associated with proventriculitis [45]. European QX like IBV strains are associated with nephropathogenicity and cystic oviducts [6,39]. In Europe, the nephropathogenicity of QX like IBV strains may have derived from the initial European nephropathogenic strains like B1648. By natural recombination events segments of the B1648 genome may have been transferred into genomes of NGA/A116E7/2006, UKr 27-11, ITA/90254/2005 and CK/SWE/0658946/10. The emergence or evolution of different coronaviral genotypes or strains by recombination events has been well documented in IBV and other coronaviruses [5,46]. Recombination analysis has suggested that the genetic recombination sites can be located in multiple genes [12]. Regions that have the highest occurrence of recombination were located on the parts of replicase transcriptase 
complex (NSP2, 3, 4, 6, 13 and 14) and spike protein. The rate of recombination may be one of the important mechanisms for generating genetic and antigenic diversity within IBV [5,46]. Accumulation of mutations and recombination events between the live vaccines and field strains likely produce novel variant strains or recombinant strains like, NGA/A116E7/2006 or Ukr27-11 [19]. These novel strains are known to cause disease epidemics in chickens and vaccination failure [12], and further studies are necessary to better understand the frequency of natural recombination events and which genes are preferentially involved in recombination.

Pairwise comparisons have shown that B1648 was closely related to pathogenic non-Mass type strains but not to Massachusetts type strains and vaccines. Based on the full-length genome, Nigerian reference IBADAN strain (NGA/A116E7/2006) was the closest relative with 91.6\% nucleotide identity. Next closest were Ukrainian (UKr 27-11) and American (Gray and JMK) strains with 91.2\% nucleotide identity. It is known that Gray is a nephropathogen and JMK is a respiratory pathogen, but the information on NGA/A116E7/2006 and UKr 27-11 strains about their tissue tropism is not available. Pairwise comparisons of 1a, Spike, $M$ and accessory proteins (3a, 3b, 4b, 4c, 5a, 5b and 6b) have suggested that B1648 was most closely related to non-Mass type strains. However, based on 1b, E and $\mathrm{N}$ proteins B1648 was closely related to both Mass and non-Mass types strains. All these comparisons have implicated that the determinants of nephropathogenicity (B1648 strain) is most probably located on the 1a, spike, $\mathrm{M}$ and accessory proteins. Some authors have hypothesized that the pathogenicity determinants of IBV may be multi-genic, and associated outside the spike protein [47-49]. With the well-studied coronavirus, murine hepatitis virus (MHV), NSP1, Nsp3 and Nsp14 have been linked with virulence [50-52]. It is very well possible that the non-structural proteins (Nsp1 to Nsp11) encoded by ORF 1a are strong candidates for being involved in the nephropathogenicity. This will be investigated in the near future.

Classification of the IBV serotypes is mainly based on the variability of the spike protein or partial S1 fragment [3,19,39,53]. According to partial S1 gene analysis, Tunisian (TN20/00), Russian (IBV-27/99 and RF/06/2007) and Slovenian (SLO/266/05) strains were clustered together with B1648. This cluster is referred to as B1648 genotype. Moreover, TN20/00 was the closest among all the reported IBV strains with 97.4\% nucleotide homology. Next closest were RF-27/99 (96.4\%), RF/06/2007 (96.1\%) and SLO/266/05 (89.4\%) [18,20,22]. The partial S1 fragment analysis has revealed that the B1648 genotype is one of the important IBV genotypes, which has been circulating in Europe and North Africa for over three decades. Although the B1648 strain outbreak has occurred in 1984, its origin remains still unidentified. This raises the question, whether B1648 type has emerged from another animal species, like MERS-CoV of humans emerged from bats/camels [54,55]. The comparison with MERS-CoV is interesting because it is also associated with kidney problems in humans. However, the phylogenetic analysis, full-length nucleotide identities and recombination analysis has shown that B1648 is distinct from other known avian and mammalian coronaviruses, and provides no information on its origin (data not shown). Based on the danger of cross species jumps of coronaviruses, more epidemiologic and surveillance studies should be done on coronaviruses in species living in the wild. Gammacoronaviruses could be circulating asymptomatically in wild birds as reservoirs, before emerging as a novel pathogenic IBV strains in chickens [56,57]. In this context, efforts should be done to generate a database of full-length sequences of coronaviruses in wild animals e.g., wild migratory birds. 
In summary, the present study has demonstrated that B1648 is a distinct strain setting it apart from all strains reported so far in Europe and other parts of the world. Partial S1 gene analysis has suggested that B1648 genotype or its variants has been circulating in Europe and North Africa for over three decades. The pathogenicity determinants of B1648 strain might be located on the 1a, spike, M and accessory proteins $(3 a, 3 b, 4 b, 4 c, 5 a, 5 b$ and $6 b)$. By reverse genetics the molecular basis of the nephropathogenicity of IBV strains will be elucidated.

\section{Acknowledgments}

This research was supported by the Indian Council of Agricultural Research (ICAR, Pusa, New Delhi-110012 (29-1/2009-EQR/Edn)). Vishwanatha RAP Reddy and Hans J Nauwynck are members of the BELVIR consortium (IAP, phase VII) sponsored by Belgian Science Policy Office (BELSPO). The authors acknowledge Magda De Keyzer and Lieve Sys for their excellent technical assistance.

\section{Author Contributions}

V.R.A.P.R. and H.J.N. conceived and designed the experiments; V.R.A.P.R. performed the experiments; S.T., I.D.M.R., J.M. and M.Z. took part in the design of the study and critically analyzed the data. J.M. contributed reagents/materials; V.R.A.P.R. and H.J.N. wrote the paper.

\section{Conflicts of Interest}

The authors declare no conflict of interest.

\section{References}

1. Cavanagh, D. Coronaviruses in poultry and other birds. Avian Pathol. 2005, 34, 439-448. [CrossRef] [PubMed]

2. Woo, P.C.; Lau, S.K.; Lam, C.S.; Tsang, A.K.; Hui, S.W.; Fan, R.Y.; Martelli, P.; Yuen, K.Y. Discovery of a novel bottlenose dolphin coronavirus reveals a distinct species of marine mammal coronavirus in Gammacoronavirus. J. Virol. 2014, 88, 1318-1331. [CrossRef] [PubMed]

3. Cavanagh, D. Coronavirus avian infectious bronchitis virus. Vet. Res. 2007, 38, 281-297. [CrossRef] [PubMed]

4. Kottier, S.A.; Cavanagh, D.; Britton, P. Experimental evidence of recombination in coronavirus infectious bronchitis virus. Virology 1995, 213, 569-580. [CrossRef] [PubMed]

5. Thor, S.W.; Hilt, D.A.; Kissinger, J.C.; Paterson, A.H.; Jackwood, M.W. Recombination in avian gamma-coronavirus infectious bronchitis virus. Viruses 2011, 3, 1777-1799. [CrossRef] [PubMed]

6. Cook, J.K.; Jackwood, M.; Jones, R.C. The long view: 40 years of infectious bronchitis research. Avian Pathol. 2012, 41, 239-250. [CrossRef] [PubMed]

7. Meulemans, G.; Carlier, M.C.; Gonze, M.; Petit, P.; Vandenbroeck, M. Incidence, characterisation and prophylaxis of nephropathogenic avian infectious bronchitis viruses. Vet. Rec. 1987, 120, 205-206. [CrossRef] [PubMed]

8. Winterfield, R.W.; Hitchner, S.B. Etiology of an infectious nephritis-nephrosis syndrome of chickens. Am. J. Vet. Res. 1962, 23, 1273-1279. [PubMed] 
9. Cumming, R.B. Infectious avian nephrosis (uraemia) in Australia. Aust. Vet. J. 1963, 39, 145-147. [CrossRef]

10. Wang, C.H.; Hsieh, M.C.; Chang, P.C. Isolation, pathogenicity, and H120 protection efficacy of infectious bronchitis viruses isolated in Taiwan. Avian Dis. 1996, 40, 620-625. [CrossRef] [PubMed]

11. Song, C.S.; Lee, Y.J.; Kim, J.H.; Sung, H.W.; Lee, C.W.; Izumiya, Y.; Miyazawa, T.; Jang, H.K.; Mikami, T. Epidemiological classification of infectious bronchitis virus isolated in Korea between 1986 and 1997. Avian Pathol. 1998, 27, 409-416. [CrossRef] [PubMed]

12. Lim, T.H.; Lee, H.J.; Lee, D.H.; Lee, Y.N.; Park, J.K.; Youn, H.N.; Kim, M.S.; Lee, J.B.; Park, S.Y.; Choi, I.S.; et al. An emerging recombinant cluster of nephropathogenic strains of avian infectious bronchitis virus in Korea. Infect. Genet. Evol. 2011, 11, 678-685. [CrossRef] [PubMed]

13. Meir, R.; Rosenblut, E.; Perl, S.; Kass, N.; Ayali, G.; Perk, S.; Hemsani, E. Identification of a novel nephropathogenic infectious bronchitis virus in Israel. Avian Dis. 2004, 48, 635-641. [CrossRef] [PubMed]

14. Mahmood, Z.H.; Sleman, R.R.; Uthman, A.U. Isolation and molecular characterization of Sul/01/09 avian infectious bronchitis virus, indicates the emergence of a new genotype in the Middle East. Vet. Microbiol. 2011, 150, 21-27. [CrossRef] [PubMed]

15. Abdel-Moneim, A.S.; El-Kady, M.F.; Ladman, B.S.; Gelb, J. S1 gene sequence analysis of a nephropathogenic strain of avian infectious bronchitis virus in Egypt. Virol. J. 2006, 3, e78. [CrossRef] [PubMed]

16. Bayry, J.; Goudar, M.S.; Nighot, P.K.; Kshirsagar, S.G.; Ladman, B.S.; Gelb, J.; Ghalsasi, G.R.; Kolte, G.N. Emergence of a nephropathogenic avian infectious bronchitis virus with a novel genotype in India. J. Clin. Microbiol. 2005, 43, 916-918. [CrossRef] [PubMed]

17. Pensaert, M.; Lambrechts, C. Vaccination of chickens against a Belgian nephropathogenic strain of infectious bronchitis virus B1648 using attenuated homologous and heterologous strains. Avian Pathol. 1994, 23, 631-641. [CrossRef] [PubMed]

18. Bochkov, Y.A.; Batchenko, G.V.; Shcherbakova, L.O.; Borisov, A.V.; Drygin, V.V. Molecular epizootiology of avian infectious bronchitis in Russia. Avian Pathol. 2006, 35, 379-393. [CrossRef] [PubMed]

19. Ducatez, M.F.; Martin, A.M.; Owoade, A.A.; Olatoye, I.O.; Alkali, B.R.; Maikano, I.; Snoeck, C.J.; Sausy, A.; Cordioli, P.; Muller, C.P. Characterization of a new genotype and serotype of infectious bronchitis virus in Western Africa. J. Gen. Virol. 2009, 90, 2679-2685. [CrossRef] [PubMed]

20. Krapež, U.; Slavec, B.; Barlič-Maganja, D.; Rojs, O.Z. Molecular analysis of infectious bronchitis viruses isolated in Slovenia between 1990 and 2005: A retrospective study. Virus Genes 2010, 41, 414-416. [CrossRef] [PubMed]

21. Tosi, G.; Taddei, R.; Barbieri, I.; Fiorentini, L.; Massi, P. Caratterizzazione molecolare dei ceppi di virus della bronchite infettiva aviare isolati in Italia nel periodo 2007-2009 e nel primo bimestre del 2010. In Proceedings of the 49th Annual Conference of Acts Italian society of Avian Pathology (SIPA), Forli, Italy, 29-30 April 2010; pp. 217-224. 
22. Bourogaa, H.; Hellal, I.; Hassen, J.; Fathallah, I.; Ghram, A. S1 gene sequence analysis of new variant isolates of avian infectious bronchitis virus in Tunisia. Vet. Med. 2012, 3, 41-48. [CrossRef]

23. Toffan, A.; Bonci, M.; Bano, L.; Valastro, V.; Vascellari, M.; Capua, I.; Terregino, C. Diagnostic and clinical observation on the infectious bronchitis virus strain Q1 in Italy. Vet. Ital. 2013, 49, 347-355. [PubMed]

24. Shaw, K.; Britton, P.; Cavanagh, D. Sequence of the spike protein of the Belgian B164S isolate of nephropathogenic infectious bronchitis virus. Avian Pathol. 1996, 25, 607-611. [CrossRef] [PubMed]

25. Bankevich, A.; Nurk, S.; Antipov, D.; Gurevich, A.A.; Dvorkin, M.; Kulikov, A.S.; Lesin, V.M.; Nikolenko, S.I.; Pham, S.; Prjibelski, A.D.; et al. SPAdes: A new genome assembly algorithm and its applications to single-cell sequencing. J. Comput. Biol. 2012, 19, 455-477. [CrossRef] [PubMed]

26. Altschul, S.F.; Gish, W.; Miller, W.; Myers, E.W.; Lipman, D.J. Basic local alignment search tool. J. Mol. Biol. 1990, 215, 403-410. [CrossRef]

27. Huang, Y.; Lau, S.K.; Woo, P.C.; Yuen, K.Y. CoVDB: A comprehensive database for comparative analysis of coronavirus genes and genomes. Nucleic Acids Res. 2008, 36, D504-D511. [CrossRef] [PubMed]

28. Wang, S.; Sundaram, J.P.; Spiro, D. VIGOR, an annotation program for small viral genomes. BMC Bioinform. 2010, 11, e451. [CrossRef] [PubMed]

29. Lambrechts, C.; Pensaert, M.; Ducatelle, R. Challenge experiments to evaluate cross-protection induced at the trachea and kidney level by vaccine strains and Belgian nephropathogenic isolates of avian infectious bronchitis virus. Avian Pathol. 1993, 22, 577-590. [CrossRef] [PubMed]

30. Cook, J.K.; Chesher, J.; Baxendale, W.; Greenwood, N.; Huggins, M.B.; Orbell, S.J. Protection of chickens against renal damage caused by a nephropathogenic infectious bronchitis virus. Avian Pathol. 2001, 30, 423-426. [CrossRef] [PubMed]

31. Hewson, K.A.; Ignjatovic, J.; Browning, G.F.; Devlin, J.M.; Noormohammadi, A.H. Infectious bronchitis viruses with naturally occurring genomic rearrangement and gene deletion. Arch. Virol. 2011, 156, 245-252. [CrossRef] [PubMed]

32. Xue, Y.; Xie, Q.; Yan, Z.; Ji, J.; Chen, F.; Qin, J.; Sun, B.; Ma, J.; Bi, Y. Complete genome sequence of a recombinant nephropathogenic infectious bronchitis virus strain in China. J. Virol. 2012, 86, 13812-13813. [CrossRef] [PubMed]

33. Abolnik, C. Genomic and single nucleotide polymorphism analysis of infectious bronchitis coronavirus. Infect. Genet. Evol. 2015, 32, 416-424. [CrossRef] [PubMed]

34. Cao, J.; Wu, C.C.; Lin, T.L. Complete nucleotide sequence of polyprotein gene 1 and genome organization of turkey coronavirus. Virus Res. 2008, 136, 43-49. [CrossRef] [PubMed]

35. Bentley, K.; Keep, S.M.; Armesto, M.; Britton, P. Identification of a noncanonically transcribed subgenomic mRNA of infectious bronchitis virus and other gammacoronaviruses. J. Virol. 2013, 87, 2128-2136. [CrossRef] [PubMed] 
36. Yang, Y.; Zhang, L.; Geng, H.; Deng, Y.; Huang, B.; Guo, Y.; Zhao, Z.; Tan, W. The structural and accessory proteins M, ORF $4 \mathrm{a}$, ORF $4 \mathrm{~b}$, and ORF 5 of Middle East respiratory syndrome coronavirus (MERS-CoV) are potent interferon antagonists. Protein Cell 2013, 4, 951-961. [CrossRef] [PubMed]

37. Ye, Z.; Wong, C.K.; Li, P.; Xie, Y. A SARS-CoV protein, ORF-6, induces caspase-3 mediated, ER stress and JNK-dependent apoptosis. Biochim. Biophys. Acta 2008, 1780, 1383-1387. [CrossRef] [PubMed]

38. Gough, R.E.; Cox, W.J.; de B Welchman, D.; Worthington, K.J.; Jones, R.C. Chinese QX strain of infectious bronchitis virus isolated in the UK. Vet. Rec. 2008, 162, 99-100. [CrossRef] [PubMed]

39. Abro, S.H.; Renström, L.H.; Ullman, K.; Isaksson, M.; Zohari, S.; Jansson, D.S.; Belák, S.; Baule, C. Emergence of novel strains of avian infectious bronchitis virus in Sweden. Vet. Microbiol. 2012, 155, 237-246. [CrossRef] [PubMed]

40. Benyeda, Z.; Mató, T.; Süveges, T.; Szabó, E.; Kardi, V.; Abonyi-Tóth, Z.; Rusvai, M.; Palya, V. Comparison of the pathogenicity of QX-like, M41 and 793/B infectious bronchitis strains from different pathological conditions. Avian Pathol. 2009, 38, 449-456. [CrossRef] [PubMed]

41. Domanska-Blicharz, K.; Minta, Z.; Smietanka, K.; Porwan, T. New variant of IBV in Poland. Vet. Rec. 2006, 158, e808. [CrossRef]

42. Krapez, U.; Slavec, B.; Rojs, O.Z. Circulation of infectious bronchitis virus strains from Italy 02 and QX genotypes in Slovenia between 2007 and 2009. Avian Dis. 2011, 55, 155-161. [CrossRef] [PubMed]

43. Valastro, V.; Monne, I.; Fasolato, M.; Cecchettin, K.; Parker, D.; Terregino, C.; Cattoli, G. QX-type infectious bronchitis virus in commercial flocks in the UK. Vet. Rec. 2010, 167, 865-866. [CrossRef] [PubMed]

44. Worthington, K.J.; Currie, R.J.; Jones, R.C. A reverse transcriptase-polymerase chain reaction survey of infectious bronchitis virus genotypes in Western Europe from 2002 to 2006. Avian Pathol. 2008, 37, 247-257. [CrossRef] [PubMed]

45. Yu, L.; Jiang, Y.; Low, S.; Wang, Z.; Nam, S.J.; Liu, W.; Kwangac, J. Characterization of three infectious bronchitis virus isolates from China associated with proventriculus in vaccinated chickens. Avian Dis. 2001, 45, 416-424. [CrossRef] [PubMed]

46. Hughes, A.L. Recombinational histories of avian infectious bronchitis virus and turkey coronavirus. Arch. Virol. 2011, 156, 1823-1829. [CrossRef] [PubMed]

47. Ammayappan, A.; Upadhyay, C.; Gelb, J.; Vakharia, V.N. Identification of sequence changes responsible for the attenuation of avian infectious bronchitis virus strain Arkansas DPI. Arch. Virol. 2009, 154, 495-499. [CrossRef] [PubMed]

48. Armesto, M.; Cavanagh, D.; Britton, P. The replicase gene of avian coronavirus infectious bronchitis virus is a determinant of pathogenicity. PLoS ONE 2009, 4, e7384. [CrossRef] [PubMed]

49. Phillips, J.E.; Jackwood, M.W.; McKinley, E.T.; Thor, S.W.; Hilt, D.A.; Acevedol, N.D.; Williams, S.M.; Kissinger, J.C.; Paterson, A.H.; Robertson, J.S.; et al. Changes in nonstructural protein 3 are associated with attenuation in avian coronavirus infectious bronchitis virus. Virus Genes 2012, 44, 63-74. [CrossRef] [PubMed] 
50. Züst, R.; Cervantes-Barragán, L.; Kuri, T.; Blakqori, G.; Weber, F.; Ludewig, B.; Thiel, V. Coronavirus non-structural protein 1 is a major pathogenicity factor: Implications for the rational design of coronavirus vaccines. PLoS Pathog. 2007, 3, e109. [CrossRef] [PubMed]

51. Eriksson, K.K.; Cervantes-Barragán, L.; Ludewig, B.; Thiel, V. Mouse hepatitis virus liver pathology is dependent on ADP-ribose- $1^{\prime \prime}$-phosphatase, a viral function conserved in the alpha-like supergroup. J. Virol. 2008, 82, 12325-12334. [CrossRef] [PubMed]

52. Sperry, S.M.; Kazi, L.; Graham, R.L.; Baric, R.S.; Weiss, S.R.; Denison, M.R. Single-amino-acid substitutions in open reading frame (ORF) 1b-nsp14 and ORF 2a proteins of the coronavirus mouse hepatitis virus are attenuating in mice. J. Virol. 2005, 79, 3391-3400. [CrossRef] [PubMed]

53. Rimondi, A.; Craig, M.I.; Vagnozzi, A.; König, G.; Delamer, M.; Pereda, A. Molecular characterization of avian infectious bronchitis virus strains from outbreaks in Argentina (2001-2008). Avian Pathol. 2009, 38, 149-153. [CrossRef] [PubMed]

54. Abdel-Moneim, A.S. Middle East respiratory syndrome coronavirus (MERS-CoV): Evidence and speculations. Arch. Virol. 2014, 159, 1575-1584. [CrossRef] [PubMed]

55. Chastel, C. Middle East respiratory syndrome (MERS): Bats or dromedary, which of them is responsible? Bull. Soc. Pathol. Exot. 2014, 107, 69-73. [CrossRef] [PubMed]

56. Kim, H.R.; Oem, J.K. Surveillance of avian coronaviruses in wild bird populations of Korea. J. Wildl. Dis. 2014, 50, 964-968. [CrossRef] [PubMed]

57. Muradrasoli, S.; Bálint, A.; Wahlgren, J.; Waldenström, J.; Belák, S.; Blomberg, J.; Olsen, B. Prevalence and phylogeny of coronaviruses in wild birds from the Bering Strait area (Beringia). PLOS ONE 2010, 5, e13640. [CrossRef] [PubMed]

(C) 2015 by the authors; licensee MDPI, Basel, Switzerland. This article is an open access article distributed under the terms and conditions of the Creative Commons Attribution license (http://creativecommons.org/licenses/by/4.0/). 